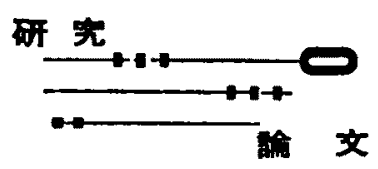

\title{
792. $\mathrm{Ni}$ 基耐熱合金鋼とセラミックコーティング材の 高温 He ガス中における摩擦・摩耗特性
}

\author{
菊地賢司*,根本 政明**, 算木 英雄*, \\ 佐野川好母*, 川口勝之**, 小野重治**
}

\author{
（1984年 2 月 2 日受理） \\ Friction and Wear Characteristics of Nickel-Based Heat-Resisting Alloy \\ and Ceramic Coating Materials in High Temperature Helium Gas
}

By Kenji KIKUCHI, Masaaki NEMOTO, Hideo KABURAKI, Konomo SANOKAWA, Katsuyuki KAWAGUCHI and Shigeharu ONO

\begin{abstract}
Relative sliding or bumping of structural elements during the operation of a very high-temperature gas-cooled reactor (VHTR), which has been developed by the Japan Atomic Energy Research Institute, are to be caused supposedly by thermal expansion, flow-induced vibration, seismic forces etc. Appropriate measures, therefore, must be taken in order to prevent abnormal wear, seizing or failure of these structural elements.

The friction and wear characteristics of Ni-based heat-resisting alloy (Hastelloy $\mathrm{X}-\mathrm{R}$ ), which is now thought to be one of the promising candidate materials for VHTR structures, and several ceramic materials by which the surfaces of Hastelloy $X-R$ are to be coated, were studied in $1,000^{\circ} \mathrm{C}$ and $0.2 \sim 4.1 \mathrm{MPa} H \mathrm{He}$ gas environment.

The followings are the conclusions derived from the present experiment:

(1) The friction coefficient of Hastelloy $X-R$ against itself decreased with increasing $\mathrm{O}_{2}$ gas partial pressure within $3 \mathrm{kPa}$ in the $\mathrm{He}$ gas environment.

(2) The mutual transfer of material elements occurred when the material combination was Hastelloy $\mathrm{X}-\mathrm{R}$ against $\mathrm{Z}_{\mathrm{rO}}$ conting.

(3) The friction and wear characteristics of $\mathrm{ZrO}_{2}$ and $\mathrm{TiC}$ coatings against themselves were stable.
\end{abstract}

KEYWORDS: HTGR type reactors, structural element, Hastelloy $X-R$, coatings, friction, wear, surface coating, zirconium dioxide, titanium carbides

\section{I . 序論}

日本原子力研究所が開発を進めている多目的高温が ス実殹妒(Very High-Temperature gas-cooled Reactor, VHTR)の高温構造要素には妒の構造上, 機器の相対 熱膨脹，冷却材の流体振動，地震力に上り相対摺動や部 材相互がぶつかり合らことがあるため，それらの部忉 の異常な摩耗，焼けつき，破損を防ぐ必要がある。この よらな目的のために，あらかしめ材料間の摩擦・摩耗 特性を把暒しておくことは重要なことと思われる(る。

一般に，高温ガス炬(High.Temperature Gas Reactor，
HTGR)の部材における擝動条件としては，次のよら な特徵がる。

（1）雾团気は改量な不純物ガスを含む高温高压の He ガス

（2）渭動材中の放射性元素の低減化

HTGRに関連したトライボジの研究はこれまでに

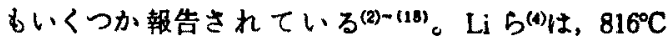

* 日本原子力研究所高温工学部(Dept. of High Temp. Eng., Japan At. Energy Res. Inst.)

**三花重工業件長崎研究所 (Nagasaki Tech. Inst., Mitsubishi Heavy Ind. Co., Ltd.) 
のHTGRの 1 次系 $\mathrm{He}$ ガス中での $\mathrm{Cr}_{23} \mathrm{C}_{6}-\mathrm{NiCr} と \mathrm{Cr}_{3} \mathrm{C}_{2}-$ $\mathrm{NiCr}$ コーティング材の低濖動速度の摩耗試鈋を行なっ t。 Engel $5^{(6)}$ は, $\mathrm{ZrO}_{2}-\mathrm{MgO}, \mathrm{Cr}_{23} \mathrm{C}_{6}-\mathrm{NiC}_{2}$ とTiC ティング材の 1 次系 $\mathrm{He}$ ガス中での両立性試験を行な った。また，村岡ら(7)，伊丹ら ${ }^{(8)}$, 野村(9)は，原研のOGL -1(Oarai Gas Loop-1)の設計·製作に祭し，耐熟材料中 黒趽の He ガス中での両立性試験を行い，村瀬ら (13)は 高温接触部の凝着举動とその防止対策を総合的に検 討し、コーティング材として $\mathrm{ZrO}_{2}-\mathrm{CaO}$ を推奖してい ろ。さらに深迫ら (14)(13) は，VHTR 用耐第合金の凝着 举動，㨐着防止法を梌討し，候補材としてMI-A 合金， $2 \mathrm{Z}_{2}-\mathrm{Y}_{2} \mathrm{O}_{3}$ と $\mathrm{CaF}_{2}-\mathrm{A}$ を提案している。著者ら(18) (18) b. VHTR の中間熱交奐器(IHX)层熱管フレッティ

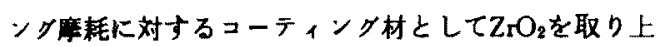
げる一方, VHTR 高温摺動部材の摩拯・摩耗举動に関
ナる一連の実検を継続して行なっている。

摩耗の基本的な機構としては，一般的に表面疲れ， アブレーション,凝着, トライボ化学反応などが考えら れるが(19)，VHTRの Heガス需囲気では，以上の効 果が相互に影辢を及ぼし合らことが予想される。

本報では，VHTR 高温摺動部材の1つである $\mathrm{Ni}$ 基 耐熱合金鋼のハステロイ X-Rに対して選んたいくつ かのコーティンタ材の摩残・摩耗特性について，その 実験結果を報告する。

ハステロイ材同士およびハステロイ材とセラミック 入の組合せは，IHXの内简管，层熱管，层熱管支持金具 と，高温配管のスライドブレート、ライナーブレート およびスペーサに用いられることになっている。 $\left(\right.$ Table 1) ${ }^{(20)}$

Table 1 Sliding conditions and combination of materials in VHTR (normal condition) ${ }^{(20)}$

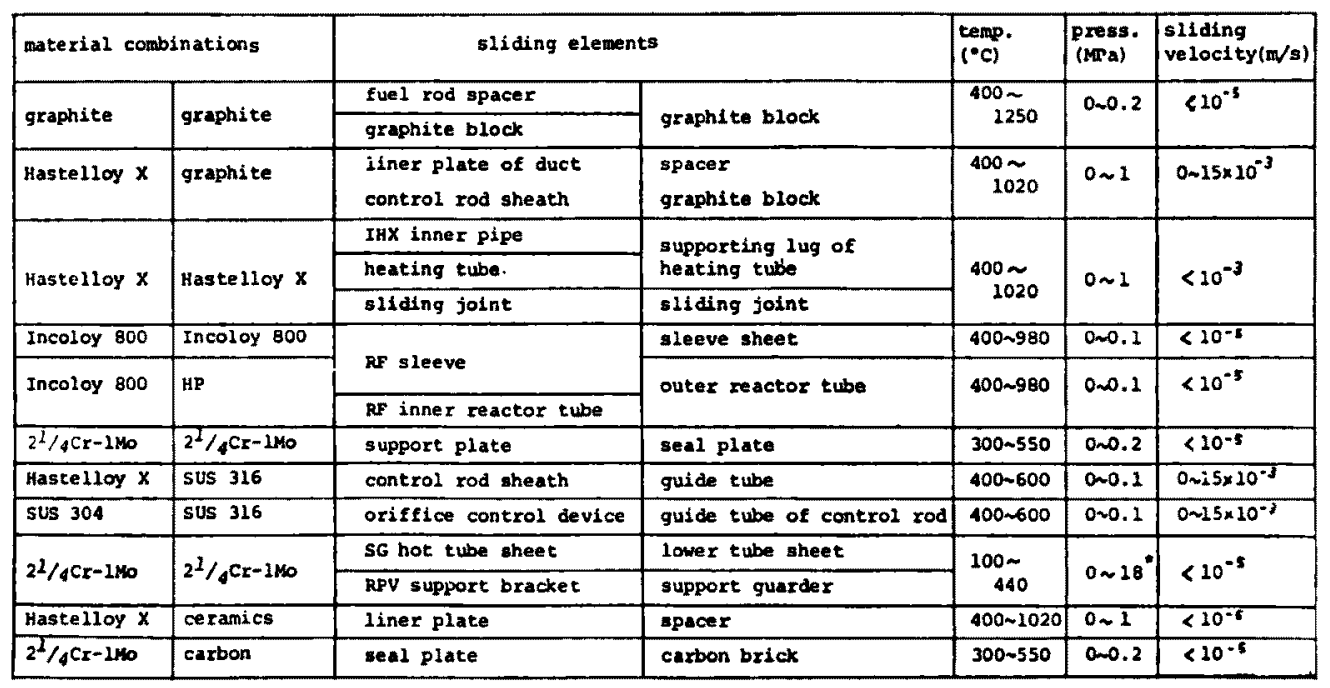

RF: Reformer, SC: Steam generator, RPV: Reactor pressure vessel, * in air

\section{II. 供践材}

ハステロイ X-Rは，耐熱材料であるハステロイX の VHTR 第囲気中における耐席食性を高めるために

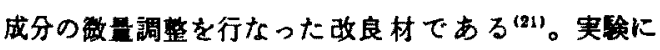
用いたハステロイ X-Rの機械的性質を Table 2 K， 化学成分をTable 3 に示す。
Table 2 Mecanical properties of Hastelloy $\mathrm{X}-\mathrm{R}$

\begin{tabular}{l|c|c}
\hline $\begin{array}{l}\text { Tensile } \\
\text { strength }\end{array}$ & $\begin{array}{l}0.2 \% \text { yield } \\
\text { strength }\end{array}$ & $\begin{array}{l}\text { Brinell } \\
\text { hardness }\end{array}$ \\
\hline $0.71 \mathrm{GPa}$ & $0.33 \mathrm{GPa}$ & 85 \\
\hline
\end{tabular}

Table 3 Chemical compositions of Hastelloy X-R ( $\%)$

\begin{tabular}{ccccccccccccccc}
\hline $\mathrm{C}$ & $\mathrm{Mn}$ & $\mathrm{Si}$ & $\mathrm{P}$ & $\mathrm{S}$ & $\mathrm{Cr}$ & $\mathrm{Co}$ & $\mathrm{Mo}$ & $\mathrm{W}$ & $\mathrm{Fe}$ & $\mathrm{B}$ & $\mathrm{Al}$ & $\mathrm{Tl}$ & $\mathrm{N}$ & $\mathrm{Ni}$ \\
\hline 0.08 & 0.9 & 0.3 & 0.005 & 0.005 & 21.96 & 0.1 & 9.18 & 0.51 & 18.28 & 0.001 & 0.05 & 0.05 & 0.005 & $\mathrm{BAL}$ \\
\hline
\end{tabular}


ハステロイ X-Rに対するコーティング材として, $\mathrm{ZrO}_{2}-\mathrm{CaC}_{2}, \mathrm{ZrO}_{2}-\mathrm{Y}_{2} \mathrm{O}_{3}, \mathrm{Cr}_{23} \mathrm{C}_{6}-\mathrm{NiCr}, \mathrm{Cr}_{2} \mathrm{O}_{3}, \mathrm{TiC}$ を選

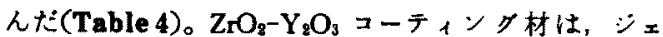

ットェンシンの好率向上にも使用されているるのであ

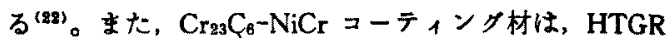
の蒸気発生器层熱管支持部にも用いられている(1)。

Table 4 Properties of coating materials

\begin{tabular}{|c|c|c|c|c|c|}
\hline Material & $\mathrm{ZrO}_{2}-\mathrm{CaC}_{2}$ & $\mathrm{ZrO}_{2}-\mathrm{Y}_{2} \mathrm{O}_{3}$ & $\mathrm{Cr}_{23} \mathrm{C}_{8}-\mathrm{NiCr}$ & $\mathrm{Cr}_{2} \mathrm{O}_{3}$ & $\mathrm{TiC}$ \\
\hline Brand & $\begin{array}{l}\text { METCO } \\
\text { 201B-NS-1 }\end{array}$ & $\begin{array}{l}\text { METCO } \\
202 \text { NS }\end{array}$ & $\begin{array}{l}\text { U.C.C. } \\
\text { LC-24 }\end{array}$ & TOCALO & MHI \\
\hline Method & Plasma spray & Plasma spray & D-gun & $\mathrm{ZAC}$ & CVD \\
\hline Bonding material & $\begin{array}{l}\mathrm{Ni}-\mathrm{Cr}-\mathrm{Al} \\
\text { METCO } 443\end{array}$ & $\begin{array}{l}\mathrm{Ni}-\mathrm{Cr}-\mathrm{Al} \\
\text { METCO } 443\end{array}$ & $\mathrm{Ni}-\mathrm{Cr}_{\mathrm{r}}$ & - & - \\
\hline Microhardness $(H v)$ & 400 & 600 & 700 & 1,000 & 3,000 \\
\hline Density $(g / c c)$ & 5.6 & 5.1 & 6.4 & - & 4.9 \\
\hline Melting point $\left({ }^{\circ} \mathrm{C}\right)$ & 2,590 & 2,480 & - & 2,435 & 3,067 \\
\hline
\end{tabular}

\section{I、試験装是と試駼片形状}

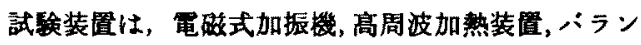
ス式試知片支持装圈などから楧成されている(18)。用 いた試験片は，平面の板状試験片を変位制御によって 正弦波状に振動させ，これに対して先端が半径 $50 \mathrm{~mm}$ の半球面の固定試鈋片を接触させたるのから構成され ている。固定試臨片は水平方向の負荷荷重により振動 試験片の两面に接触して 2 個設樭されており，2組の 試験が同時に行えるようになっている。両試験片は， 高周波コイルで加熱され，雾围気ガスは摺動面近くに 設圈された 2 本のノズル孔より直接揂動面に吹き付け られる(Fig. 1)。瀷動面の表面温度は，その近傍に取 り付けられた Pt-PtRh 熱電対で検出して制御される。

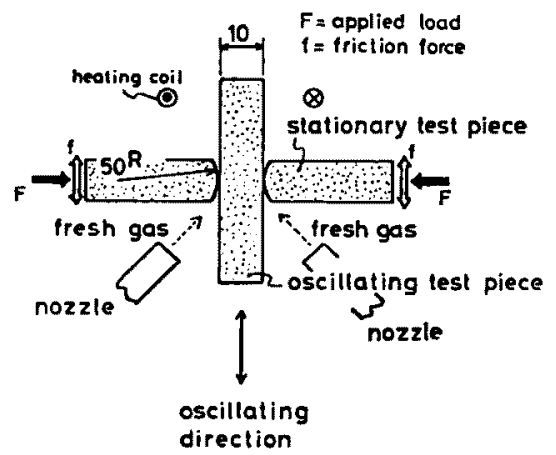

Fig. 1 Stationary and oscillating test pieces

\section{IV. 式糇条件と方法}

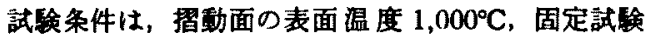
片への負荷荷重 $9.8 \mathrm{~N}$ ，振動試片の周波数 $5 \mathrm{~Hz}$ ，振幅 $0.5 \mathrm{~mm}$ 、摺動速度 $10 \mathrm{~mm} / \mathrm{s}$ ， ズル1本当りの流量

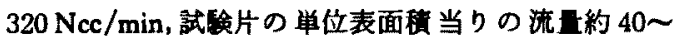

$50 \mathrm{Ncc} / \mathrm{min}$, ガス王力0.2 4.1 MPa，試験時間 $3 \mathrm{~h}$ (一部の試験は $300 \mathrm{~h}$ )である。

ハステロイ X-R 同士の摺動に対して用いた雾囲気 ガスは，不純物ガスとして $\mathrm{O}_{2}, \mathrm{H}_{2} \mathrm{O}, \mathrm{H}_{2}, \mathrm{CH}_{4}$ を含む He ガスと，純 Heガス(不粘物ガス 1 ppm以下)であり， ハステロイ X-R とコーティンク材史たはコーティン グ材同土の摺動に対して用いた䨌围気がスは，材料試 検用不純物調整 He ガスの原研Bガス(Table 5，实䧗 はBガスの分在比と同じ比率の涅合がス)である。

Table 5 Compositions of JAERI-B gas (Pa)

\begin{tabular}{ccccccc}
\hline $\mathrm{H}_{2}$ & $\mathrm{H}_{2} \mathrm{O}$ & $\mathrm{CO}$ & $\mathrm{CO}_{2}$ & $\mathrm{CH}_{4}$ & $\mathrm{~N}_{2}$ & $\mathrm{He}$ \\
\hline 20 & 0.2 & 10 & $0.1 \sim 0.2$ & 0.5 & $<0.5$ & $\mathrm{BAL}$ \\
\hline
\end{tabular}

純 $\mathrm{He}$ ガス中に存在する不純物ガス，および装置か ら放出される不純物ガスがあることを考虑して，ガス クロマトグラフと水分計により試験容器の入口と出口 の不純物ガス灌度の測定を行なった。おのおのの試㗑 における試験容器入口の測定值と、試験に用いた材料 との組合せをTable 6 に示す。

ハステロイ X-R の振動試験片の最終仕上げは，\# $1500 の エ メ リ 一$ 紙, 固定試銐片については旋盤によっ て行い，両試検片の粗さの最大高さ $\left(R_{\max }\right) は 1 \sim 3 \mu \mathrm{m}$ であった。コーティング材については研磨せずにその ままとした。その最大高さは $\mathrm{ZrO}_{2} て 50 \mu \mathrm{m}$, その他 のコーティンク材で数 $\mu \mathrm{m}$ であった。

試検の手順は次のとおりりである。方試験片を1,000 ○Cに加熱し，荷重を加えた後，振動試験片を加振した。 試検終了後は荷重を除去し，加振を止めてから陚検容 器内で徐命した。

試䋡終了後の摺動面の中心部分の表面粗さを摺㲜方 向とそれに直角な方向について测定し，その平姁值を 
Table 6 Test conditions and combination of materials

\begin{tabular}{|c|c|c|c|c|c|c|c|c|c|c|c|}
\hline No & $\begin{array}{l}\text { oscillofing } \\
\text { test piece }\end{array}$ & $\begin{array}{l}\text { stotionary } \\
\text { test piece }\end{array}$ & \multirow{2}{*}{\multicolumn{2}{|c|}{ 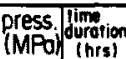 }} & \multicolumn{6}{|c|}{ parfial pressure of impurity gas $(\mathrm{PO}){ }^{\prime}$} & ref \\
\hline 1 & \multirow{10}{*}{\multicolumn{2}{|c|}{ Hostelloy $X-R$}} & & & $\frac{U_{2}}{8+104}$ & $\frac{\mathrm{H}_{2} \mathrm{O}}{07210^{-1}}$ & - & $\mathrm{CH}_{4}$ & $\frac{100}{04 \times 10^{-1}}$ & $\mathrm{Cu}_{2}$ & \\
\hline 2 & & & 0.2 & \multirow{19}{*}{3} & & $3.540-1$ & $=$ & - & - & $03 \times 10^{-1}$ & 0, effect \\
\hline \begin{tabular}{|l|}
3 \\
4 \\
\end{tabular} & & & 4.1 & & \begin{tabular}{|l|l|}
$5,3 \sqrt{10}$ \\
$25 \times 10^{3}$
\end{tabular} & $\frac{104}{34}$ & $\bar{z}$ & $\overline{-}$ & $\frac{1.5}{21}$ & $=$ & \\
\hline \begin{tabular}{|l|}
5 \\
6
\end{tabular} & & & 0.2 & & $0.1 \times 10^{4}$ & $\frac{11}{23.10}$ & $\overline{-}$ & $=$ & - & $\overline{-}$ & S0 atton \\
\hline-7 & & & 41 & & $5.6 \times 10^{-1}$ & $3.9 \times 10$ & 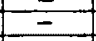 & - & 1.1 & E & Hzo entect \\
\hline 8 & & & & & \begin{tabular}{|l|}
$1.310^{-1}$ \\
0.4007
\end{tabular} & $\frac{2,0.10^{3}}{0.8 .10^{-1}}$ & $=$ & $\overline{-}$ & $\frac{7.6 \times 10^{-1}}{0.3 \times 10^{-1}}$ & $\bar{z}$ & \\
\hline 10 & & & 0.2 & & $0.3 \times 10^{-1}$ & $1,3.10^{-1}$ & $12 \times 10^{2}$ & $=$ & - & $=$ & H, effect \\
\hline$\frac{11}{12}$ & & & 4.1 & & \begin{tabular}{|l|}
1.2 \\
$76=10-1$ \\
\end{tabular} & $5.2 \times 10^{-1}$ & $\frac{1,2 \times 10}{3,103}$ & $\overline{-}$ & $=$ & $\overline{-}$ & \\
\hline \begin{tabular}{|c|}
13 \\
14 \\
\end{tabular} & & & \multirow{13}{*}{0.2} & & $\frac{0.210^{-1}}{0.10^{-1}}$ & $\frac{4.1 \times 10^{-1}}{3.7 \times 10^{-1}}$ & $02 \times 10^{-1}$ & 1, & $\frac{0.2 \times 10^{-1}}{0.1}$ & $=$ & $\mathrm{CH}_{4}$ effeci \\
\hline 15 & & & & & -1 & 02 & - & - & $-3 \times 10$ & $=$ & pure He \\
\hline 16 & & $\mathrm{ZrO}_{2}-\mathrm{COC}_{2}$ & & & $0.1 \times 10^{-1}$ & $23 \times 10^{-1}$ & $2.2 \times 10$ & $5.0 \times 10^{-1}$ & $11 \times 10$ & $1.6 \times 10^{-1}$ & \multirow{11}{*}{ JAERI-B gos } \\
\hline 17 & $U$ Uatala $y-0$ & $\mathrm{Crax}_{6}$ & & & $0.1 \times 10^{-1}$ & $2.3 \cdot 10^{-1}$ & $2.2 \times 10$ & $5,0,10^{-1}$ & $1,1.10$ & $1,6 \times 10^{-1}$ & \\
\hline 18 & Hosielloy $x-R$ & $\frac{\operatorname{lic}}{\operatorname{cts}_{0} 0_{3}}$ & & & $=$ & $0,4 \times 10^{-1}$ & $2.1 \times 10$ & $52410^{-1}$ & $1,1 \times 10$ & $\frac{13 \times 10-1}{13=1}$ & \\
\hline 20 & & $2 \mathrm{rO}_{2}-\mathrm{Y}_{2} \mathrm{O}_{3}$ & & & $=$ & $\frac{23.101}{23 \times 10^{-1}}$ & $\frac{1.100}{2.10}$ & $5,2 \times 10^{-1}$ & $\frac{1.1710}{1.1 \times 10}$ & $15 \times 10^{-1}$ & \\
\hline 21 & $2 \mathrm{rO}_{2}$ & $-\mathrm{COC}_{2}$ & & & - & $2.3 \times 10^{-1}$ & $2.1 \times 10$ & $52 \times 10^{-1}$ & $1,1 \times 10$ & $15 \times 10^{-1}$ & \\
\hline 22 & $\mathrm{Cr}_{23 \mathrm{C}}$ & & & & $0,2410^{-4}$ & $1.9 \times 10^{-1}$ & $2,2.10$ & $56 \times 10^{-1}$ & 1.210 & $1.6 \times 10^{-1}$ & \\
\hline 23] & TiC & & & & $0.5 \times 10-1$ & $1.0 \times 10^{-1}$ & $2.0 \times 10$ & $48 \times 10-1$ & $1.1 \times 10$ & $1.2 \cdot 10^{-1}$ & \\
\hline 24 & $\mathrm{Cr}_{22} \mathrm{O}_{3}$ & & & & $0.5 \times 104$ & $1.0 .10^{-1}$ & $2.0 \times 10$ & $4.8 \times 10^{-1}$ & $1.1 \times 10$ & $1.2 \times 10^{-1}$ & \\
\hline 25 & $\mathrm{ZrO}_{2}$ & $-Y_{2} \mathrm{O}_{3}$ & & & 0.2104 & $1.9 \times 10^{-1}$ & $2.2 \times 10$ & $56110^{-1}$ & $1,2 \times 10$ & $1,6 \times 10^{-1}$ & \\
\hline \begin{tabular}{|l|}
26 \\
27 \\
\end{tabular} & Hostelloy $x \rightarrow$ & $2 \mathrm{rO}_{2} \cdot \mathrm{COC}_{2}$ & & & 0 2.104 & $0.4 \times 10^{-1}$ & $2.1 \times 10$ & $54 \times 10^{-1}$ & $1.1 \times 10$ & $1.6 \times 10^{-1}$ & \\
\hline 27 & $2 \mathrm{rO}_{2}$ & $-\mathrm{CaC}_{2}$ & & & 0.200 & $0,4 \times 10^{-1}$ & $2,1 \times 10$ & $54 \times 10^{-1}$ & $1.1 \times 10$ & $16 \times 10^{-1}$ & \\
\hline
\end{tabular}

代表值とした。摩耗㾗の観察には光学顕微鏡と走查型 電子影琙鏡，元素分析にはX線マイクロフナライザ, 反応生成物の同定にはX線回折を用いた。

また，摩撩係数は，固定陚験片の腕に取り付けられ たロードセルにより測定された摩掽力の最大値 $f_{\max }$ と最小值 $f_{\mathrm{min}}$ との差と，固定試験片に負荷された荷 重 $F$ から次式により求めた。

$$
\mu=\frac{1}{2 F}\left(f_{\max }-f_{\min }\right)
$$

\section{V. 試伢 結 果}

\section{1. 整数}

ハステロ1 X-R 同士の相対摺動では，不純物ガス

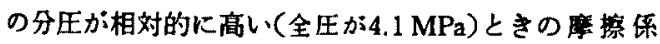
数は，分王が低い(全压が0.2 MPa)ときに比べて翇動 距礁が大きくなる任と安定な值を示している(Fig.2)。 四中の渡 $C$ は使用した雾国気がスの大体の目安を 示したるのであり，湘定值ではない。特に， $\mathrm{O}_{2}$ を $10^{8}$ vpm 含んだ He ガス中の等探数は，試験開始直後に 高い值を示してから，場合によっては徐々に低下し たり $(0.2 \mathrm{MPa})$ ，または急湤に低下したり $(4.1 \mathrm{MPa}) し$ ているが，結局的 0.3 の低い値に落ち着いている。

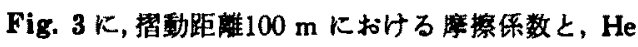
ガス中に添加した混合ガスの分正との肉俰を示すか， $\mathrm{O}_{2}$ 分王の增加につれて革撩俰数は低下している。同じ よらな㑯向は $\mathrm{H}_{2} \mathrm{O}$ の分压についてむ梁められる。
原研 Bガス中におけけるハステロィ X-R(固定片)と コーティング材(振䡃片)およびコーティンク材同士の 摩摖特性を Fig. 4 に示す。ハステロイ X-R とコーテ ヘンタ材の摺動では, $\mathrm{ZrO}_{2}-\mathrm{CaC}_{2}, \mathrm{ZrO}_{2}-\mathrm{Y}_{2} \mathrm{O}_{3}, \mathrm{Cr}_{2} \mathrm{O}_{3}$ が比較的安定で，摩擦保数は0.7〜1.2であった。しか

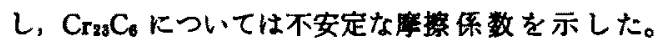

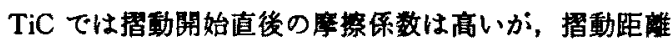
が長くなると減少して1.4になった。ューティング林同 士の摺動については，摺動距離が $25 \mathrm{~m}$ 付近で急湤に 高い摩㨲係数を示した $\mathrm{Cr}_{2} \mathrm{O}_{3}$ 以外は比较的安定であっ た。 $\mathrm{TiC}$ の摩㮩係数は最も低く $0.5 \sim 0.75, \mathrm{ZrO}_{2}-\mathrm{CaC}_{2}$ は約0.9, $\mathrm{ZrO}_{2}-\mathrm{Y}_{2} \mathrm{O}_{3}$ は1.1〜1.3であった。

Fig. 5 は, $2 \mathrm{rO}_{2}-\mathrm{CaC}_{2}$ ニーティング材の畏時間におけ る摩祭特性を示す。コーティング林同士の摩擦保数は 0.6〜0.9, ハステロイ X-Rとコーティング材の摩擦倸 数は0.3〜1.0であり，前者の方が変轩滆が小さい。

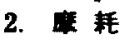

ハステロイ X-R 同士の摩耗特性について，摺動面 の表面粗さの変化および摩耗痕の幅に対する不純物ガ ス没度の影锌を調べた。摺動後の表面粗さは，固定試 験片と振動試験片とでは様子が異なる。固定試検片の 表面粗さは谷の方に漏った形となり，その潹さはー10 〜ー50 $\mu \mathrm{m}$ であるのに対して，振䡃試検片の表面粗

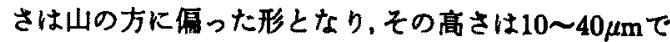
あった。 $\mathrm{O}_{2}$ 舟圧が大きくなると谷の深さ，山の高さと あに大きくなる㑯向がある。摩耗痕の幅については, 


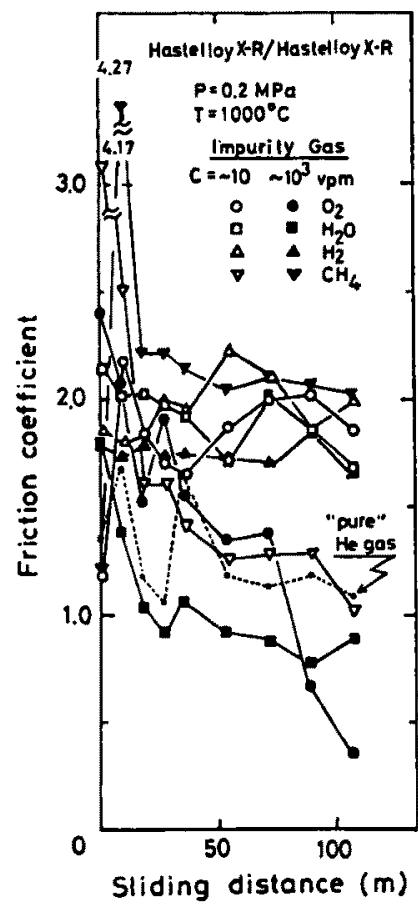

(a) At $0.2 \mathrm{MPa}$

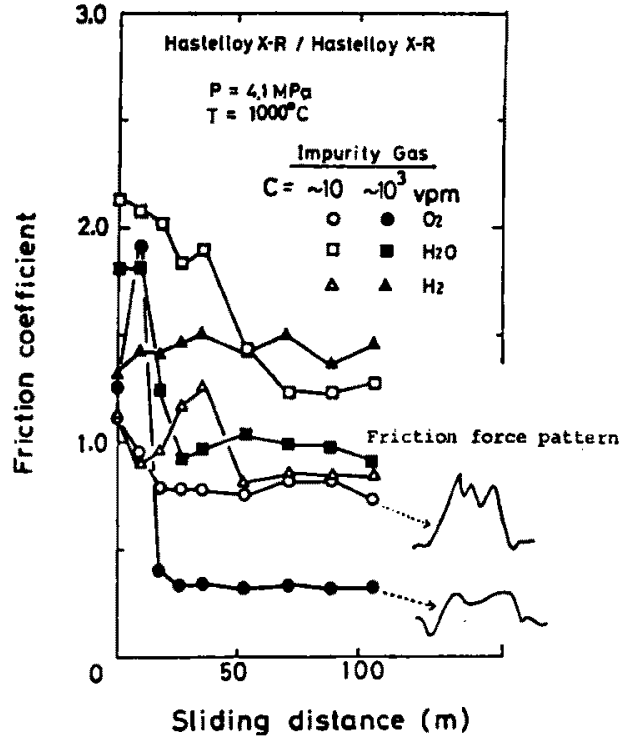

(b) At $4.1 \mathrm{MPa}$

Fig. 2 Friction coefficients as a function of sliding distance

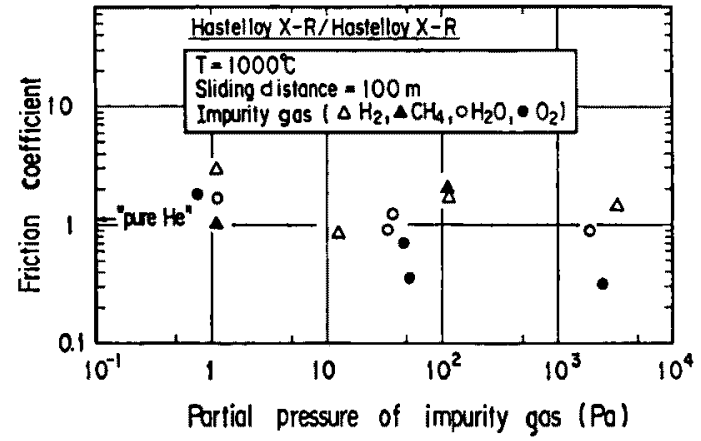

Fig. 3 Friction coefficients as a function of partial pressure of impurity gas

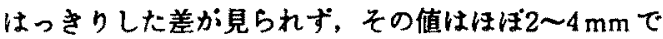
あった。

Fig.6は，原研Bガス中でのハステロ $1 \mathrm{X}-\mathrm{R}$ とコー ティング材，およびコーティンク材同士の替䡃距離100 mk光ける摩耗特性を示す。表面粗さの変化幅が最も 少ないのは TiC 同士の場合で, $-3 \sim-1 \mu \mathrm{m}$ であっ た。 TiC コーティング材と八ステロイ X-R の組合せ では、コーティング材の摩耗痕は厚さ10 $10 \mathrm{~m}$ 程度の

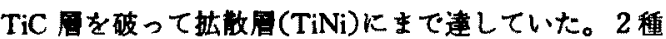
類の $\mathrm{ZrO}_{2}$ コーティング村の表面粗さの変化や摩耗痕 の愊は同じらな值を示しているので，安定化材によ

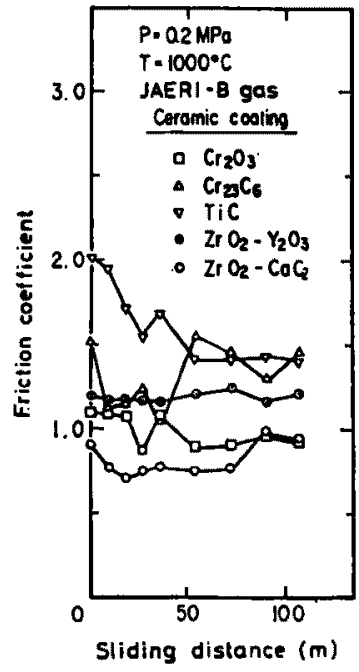

(a) Hastelloy $\mathrm{X}-\mathrm{R} /$ ceramic coating

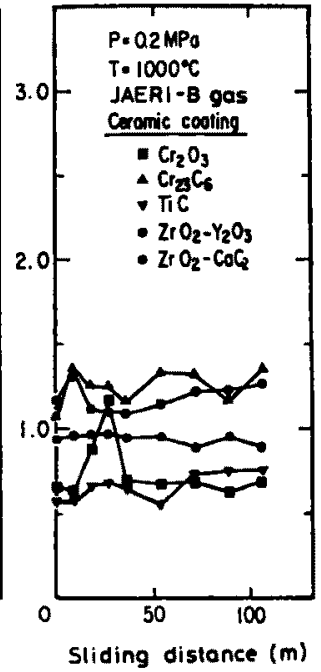

(b) Ceramic coating/ ceramic coating

Fig. 4 Friction coefficients as a function of sliding distance

る摩耗特性の変化はないと思われる。さらに， $\mathrm{ZrO}_{2}$ コーティング材の長時間試呀 $(300 \mathrm{~h})$ の結果, 表面粗 さの変化は，ハステロイX-R アコーティンク材の替 動試片によらず時間に比例した增加を示さなかった。 
また，耕痕の幅は2〜3 $3 \mathrm{~mm}$ で摺動距矆による変化は なかった。

\section{3. 表面理莱}

ハステロイ X-R 同士の摺動で，低い摩擦俰数を示 した高い $\mathrm{O}_{2}$ 分圧雾囲気の場合と，高い革禁保数を示 した低い $\mathrm{O}_{2}$ 分王雾用気の場合の摺動表 面と，その断 面の代表例を比较する。Photo. 1 は，0.3の低い摩擦保 数を示した試駼片の表面状熊を示して招り，抬大され た摺動表面(中段の写真)に摺動方向に平行な筋状の10 $\sim 50 \mu \mathrm{m}$ 幅の痕跡が見られる。エッチンクされた断面 (下段の写真)を見ると，深くえぐられた母材の上に40

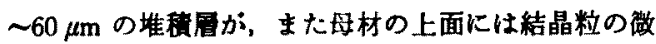
紐化層が譩められる。

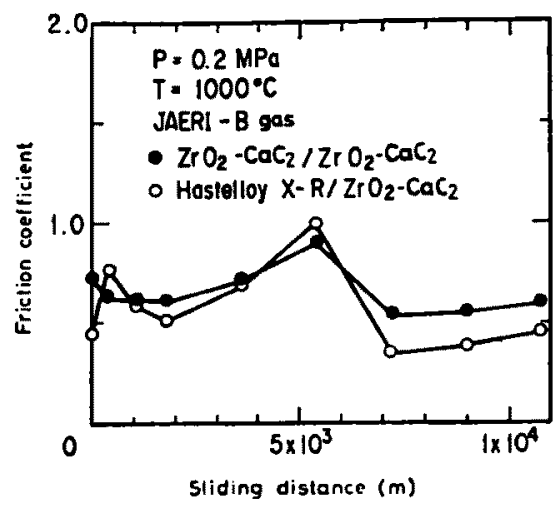

Fig. 5 Friction coefficients as a function of sliding distance $\left(\mathrm{ZrO}_{2}-\mathrm{CaC}_{2}\right.$ coating $)$

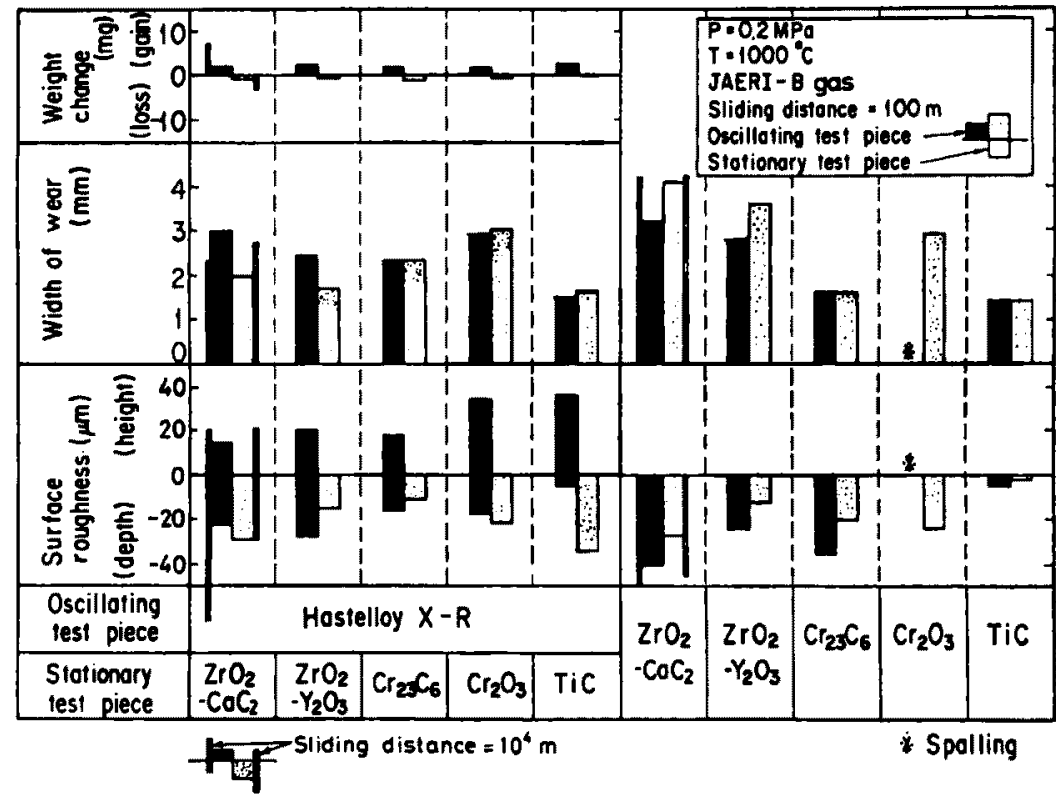

Fig. 6 Properties of sliding wear

一方，Photo. 2 に示すよ5に高い摩榇係数を示した

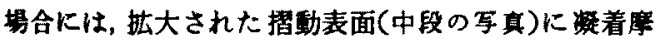

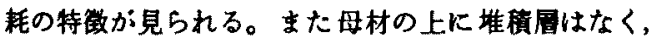

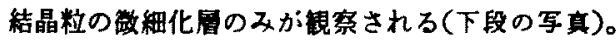

ハステロイX-Rとコーティング材との摺釛では，

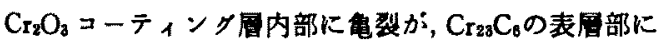

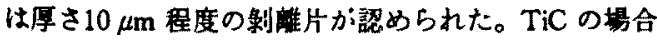
には摺動面の中央部でコーティング表居部の $\mathrm{TiC}$ 凰 かi部分的に消失し，摩耗痕は金属母材の抬散周( TiNi) に達していた。 $\mathrm{ZrO}_{2}-\mathrm{CaC}_{2}$ では，振䡃片のハステロイ $\mathrm{X}-\mathrm{R}$ 表面に，取大 $40 \mu \mathrm{m}$ 程度のコーティンク材と八 ステロイ X-Rの湦合周か，また固定片のコーティン
グ局表面の一部には、ハステロイ X-R の物質が移着し ている厚さ $10 \mu \mathrm{m}$ 程度の周が覞察された。ハステロイ

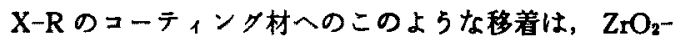
$\mathrm{Y}_{2} \mathrm{O}_{3}$ コーティング材の場合にる钼察された。 セラミックコーティング材同士の摺動では， $\mathrm{Cr}_{2} \mathrm{O}_{3} の$ 摺動面に制離が生して摺動痕が消失しており， $\mathrm{Cr}_{23} \mathrm{C}_{8}$ の固定片には母材にまで達する網目状の慜が生じて いた(Photo. 3(c))。TiCでは，摺動面かi白色から赤禓色 に変化し革耗が非常に少なかった(Photo. 3(d))。をた， Z $\mathrm{rO}_{2}-\mathrm{CaC}_{2}$ (Photo. 3(a)) と $\mathrm{ZrO}_{2}-\mathrm{Y}_{2} \mathrm{O}_{3}$ (Photo. 3(b)) では 端細に碎かれた摩耗粉によりューティング展表面の山 凸が平埋化されていた。 
$\mathrm{Z}_{2} \mathrm{O}_{2}-\mathrm{CaC}_{2}$ コーティング材とハステロイ $\mathrm{X}-\mathrm{R}$ の300 hの摺動試験では，コーティング材のハステロイ X-R への移着により混合層厚さは $3 \mathrm{~h}$ の短時間試験の場合 よりやや增加し，摺勏面中央では約 $70 \mu \mathrm{m}$ の厚さとな っていた(Photo. 4)。

\section{4. 微小組の分析}

改小組織を調べるため，X線マイクロフナライザに よる元素分析と，X線回折による反応生成物の同定と を行なったところ，ハステロイ X-R 同士の摺動で0.3
の低い摩撩係数を示した試験片の摺動断面に MnとCI の酸化物の堆積層が観察された。

また, ハステロイ X-R と $\mathrm{ZrO}_{2}-\mathrm{CaC}_{2} \ngtr \mathrm{ZrO}_{2}-\mathrm{Y}_{2} \mathrm{O}_{8}$ コーティング材の摺動では，ハステロイ X-Rにコー ティンク材の移着が認められ，厚い混合首を形成して いた。代表例として，300 h の摺動試軮におけるZ $\mathrm{CaC}_{2}$ コーティング材の混合層断面について元素分析を 行なった結果，黒色の移着物質には Mn とCrの酸化物 たけでなく $\mathrm{ZrO}_{2}$ む含まれていた(Photo.5)。
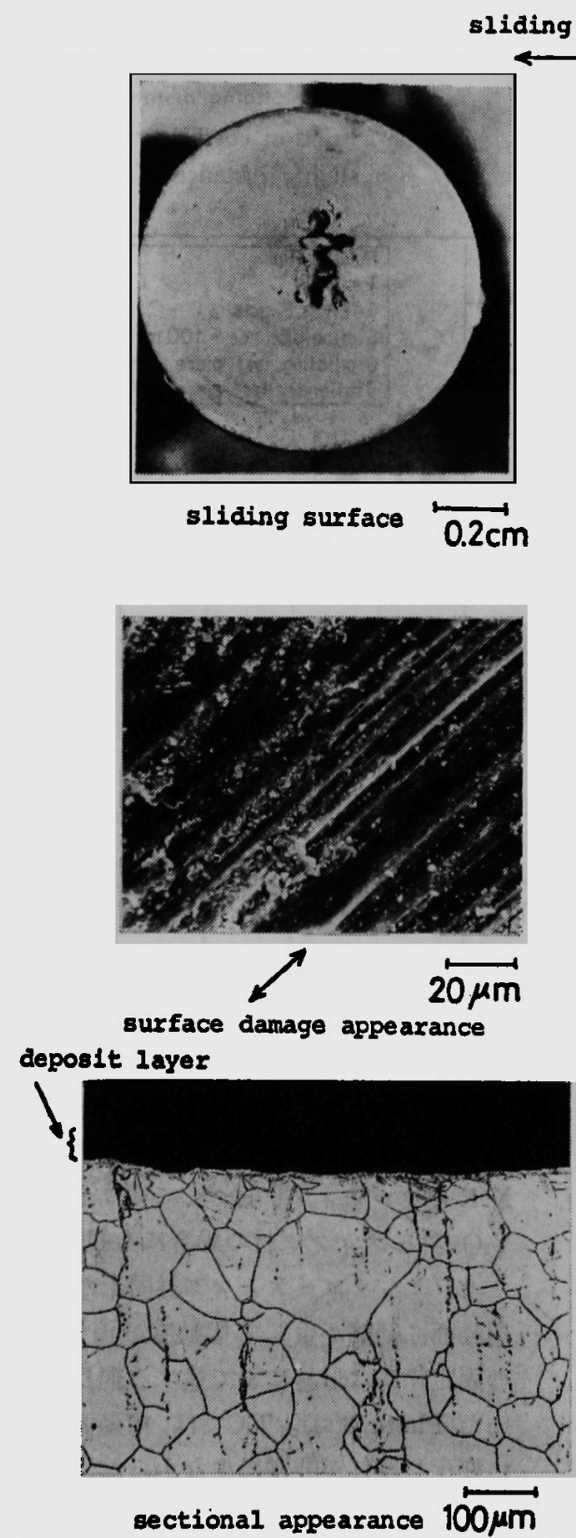

(a) Stationary test piece (Hastelloy $\mathrm{X}-\mathrm{R}$ ) Photo. 1 Optical metallographs of sliding test pieces $\left(P_{0}=2.5 \times 10^{3} \mathrm{~Pa}\right)$
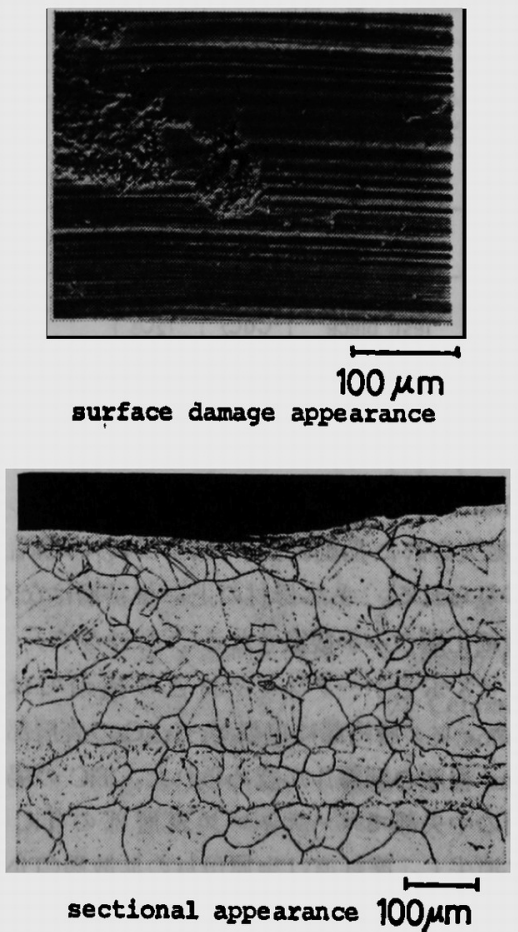

(b) Oscillating test piece (Hastelloy $\mathrm{X}-\mathrm{R}$ ) 
$\mathrm{TiC}$ コーティング材同士の摺動では，試呀片の表面 が赤褐色に変化していた。X線回折の結果,これは $\mathrm{TiC} コ$ ニィンク層の表面に形成された䄪 $1 \mu \mathrm{m}$ の薄 い $\mathrm{Ti}_{2} \mathrm{O}_{3}$ の凬であることがわかった。

\section{V. 討 詇}

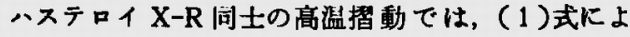
り定義される摩擦保数は摺動開始值後の高い值を除け
ば 0.3〜2であった。この中で約0.3の低い摩擦係数を 示した雾讲気ガスは，He ガス中に不純物ガスとして $\mathrm{O}_{2}$ を多量 $(50 \mathrm{~Pa} \sim 3 \mathrm{kPa})$ に含んでいた。特に, $\mathrm{O}_{2}$ 分 压が $3 \mathrm{kPa} て ゙$ 試験開始直後より安定で低い摩擦係数を 示した場合には，瀷動面上に堆箖された $\mathrm{Mn}$ と $\mathrm{Cr}$ の 40 60 $\mu \mathrm{m}$ の酸化物層を仲立ちにした 3 固体間のフブ レシブ摩耗(19)になっていると考えられる。

ところで, VHTRの1次系泠却材のような高温の

sliding direction

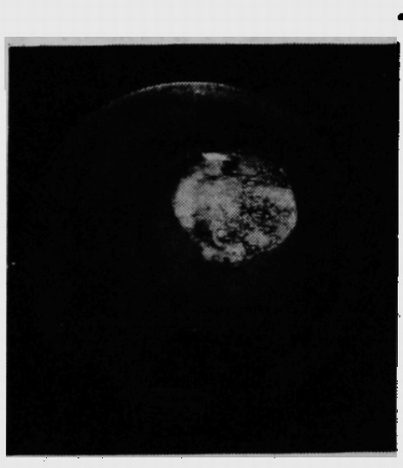

sliding surface $\overparen{0.2 \mathrm{~cm}}$

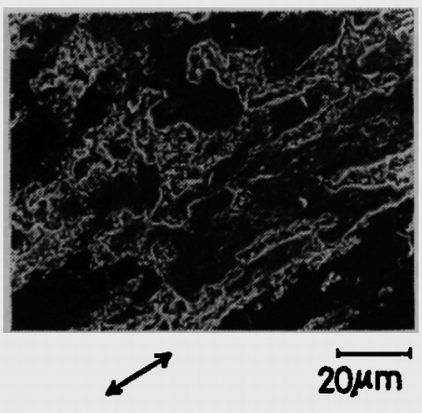

surface damage appearance

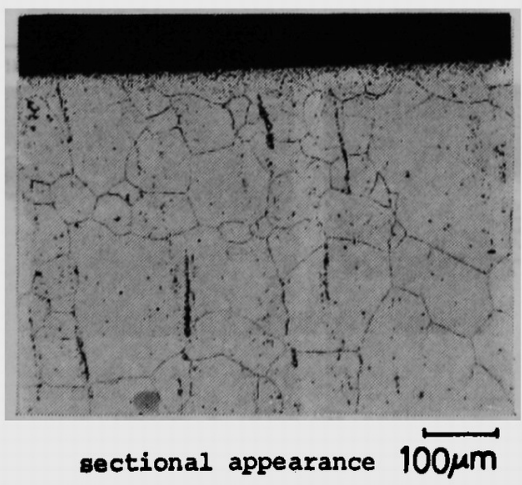

(a) Stationary test piece (Hastelloy X-R)
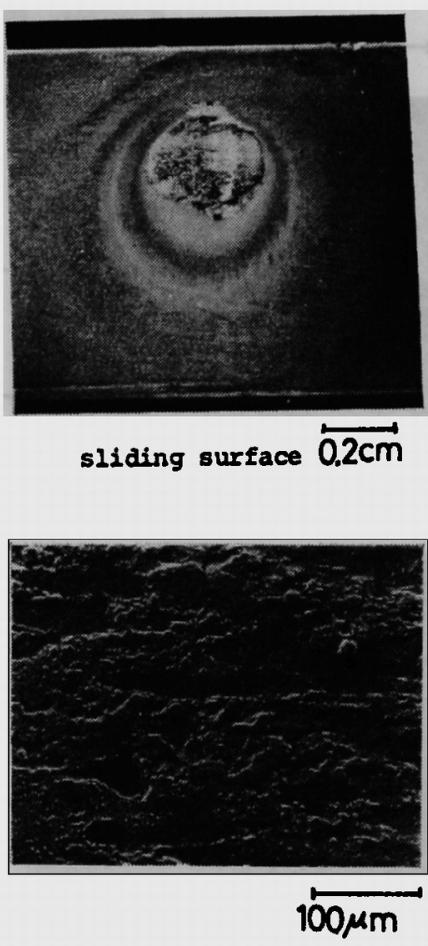

surface damage appearance

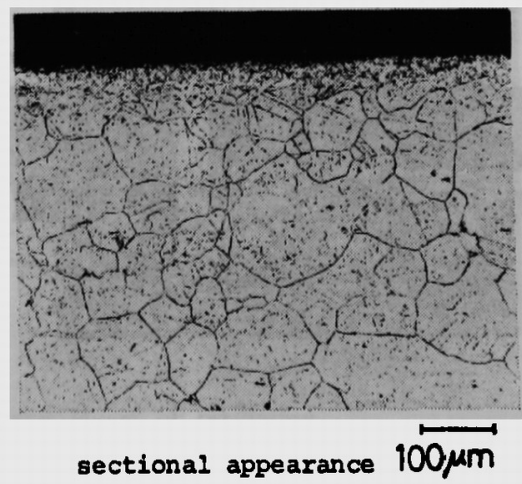

(b) Oscillating test piece (Hastelloy $\mathrm{X}-\mathrm{R}$ )

Photo. 2 Optical metallographs of sliding test pieces $\left(P_{\mathrm{H}_{2}}=3.3 \times 10^{8} \mathrm{~Pa}\right)$ 
多成分系ガスでは，酸素ポテンシャルおよび炭素ポテ ンシャルが金属合金の属食に複雑な影䇾を与えている と考えられる。そこで, 摺動面近傍で混合がスが 1,000 ${ }^{\circ} \mathrm{C}$ 高温平衡に達しているすのと仮定して，Fig. 3 の 結果を $\mathrm{O}_{2}$ の平衡分王を用いて再検討してみることに した。多成分系における高温ガスの熱力学的平衡は， 質量保存則が成り立つ場合，ギッブスの自由エネルギ 一が成分 $i$ のモル数 $\left(n_{1}\right)$ について最小であるときに成 立する。

$$
G_{T}=\sum n_{i}\left(G_{i}{ }^{0}+R T \ln a_{i}\right)
$$

この平衡計算に Besmann によって開発された計算コ 一ドのSOLGASMIX-PV (28)を用いて得た結果がFig. 7 である。 $\mathrm{O}_{2}$ の平衡分王が $1 \mathrm{~Pa}$ まで摩撩係数が0.9 3 となり，はっきりした傾向は見られないか，平衡分 压が $1 \mathrm{~Pa}$ 以上になると，平衡分压が大きなるにつれ て摩擦係数が低下している。 $\mathrm{O}_{2}$ 分圧が $1 \mathrm{~Pa} \sim 3 \mathrm{kPa}$ の 範讲における摩擦係数の值を最小自乗法で整理すると

$$
\mu=1.1 \times P_{0}{ }^{-0.17}
$$

となる。

摺動特性に及ぼす需囲気圧力の影整について，渡辺 $\longleftrightarrow$ sliding direction

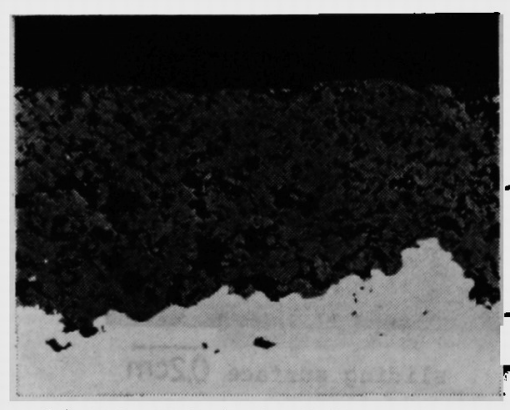

(a) $\mathrm{ZrO}_{2}-\mathrm{CaC}_{2} / \mathrm{ZrO}_{2}-\mathrm{CaC}_{2}$ coating

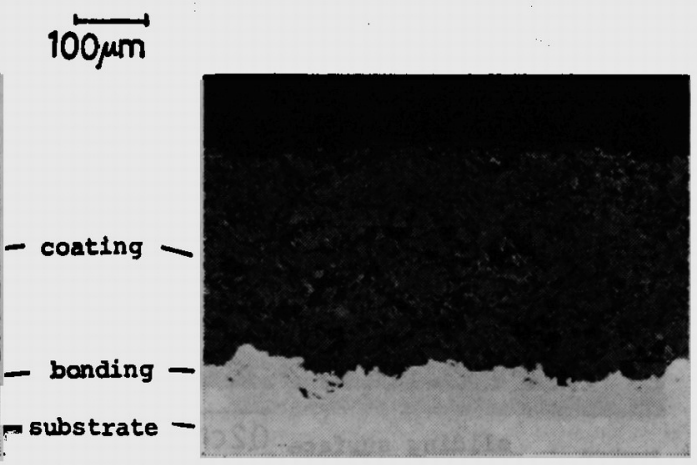

(b) $\mathrm{ZrO}_{2}-\mathrm{Y}_{2} \mathrm{O}_{3} / \mathrm{ZrO}_{2}-\mathrm{Y}_{2} \mathrm{O}_{3}$ coating

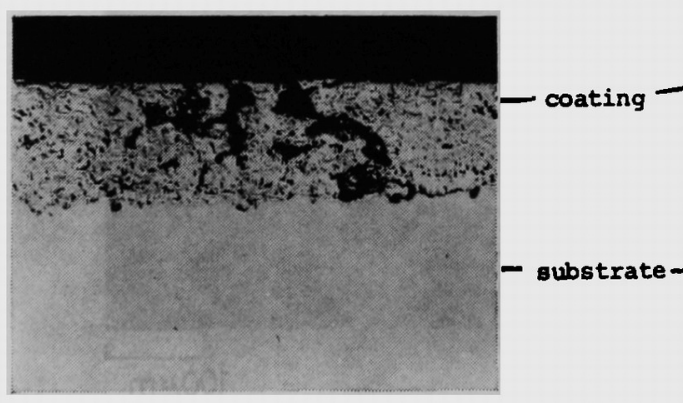

(c) $\mathrm{Cr}_{23} \mathrm{C}_{8} / \mathrm{Cr}_{28} \mathrm{C}_{6}$ coating

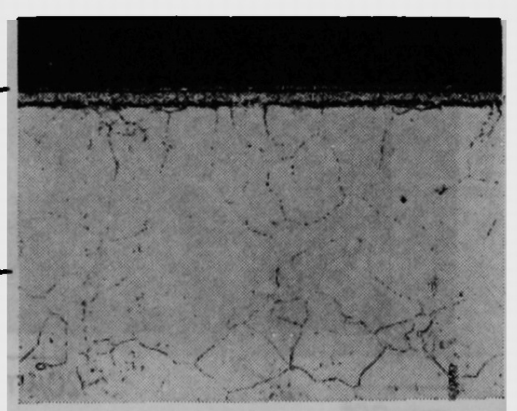

(d) $\mathrm{TiC} / \mathrm{TiC}$ coating

Photo. 3 Microstructure of sectional oscillating test pieces in JAERI-B gas

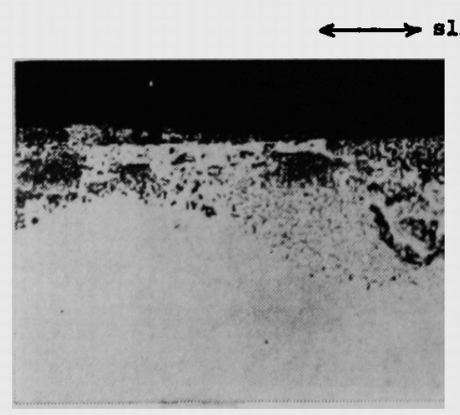

(a) Edge part

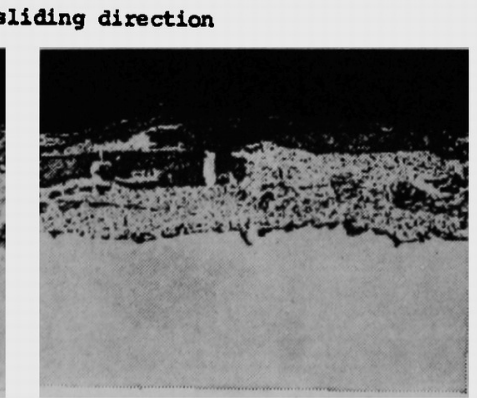

(b) Center part

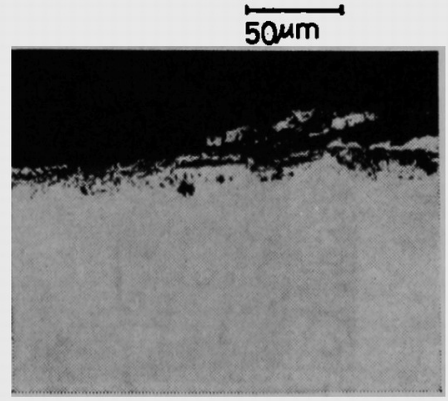

(c) Edge part

Photo. 4 Optical micrographs of sectional oscillating Hastelloy $\mathrm{X}-\mathrm{R}$ test piece against $\mathrm{ZrO}-\mathrm{CaC}_{2}$ coating test piece 


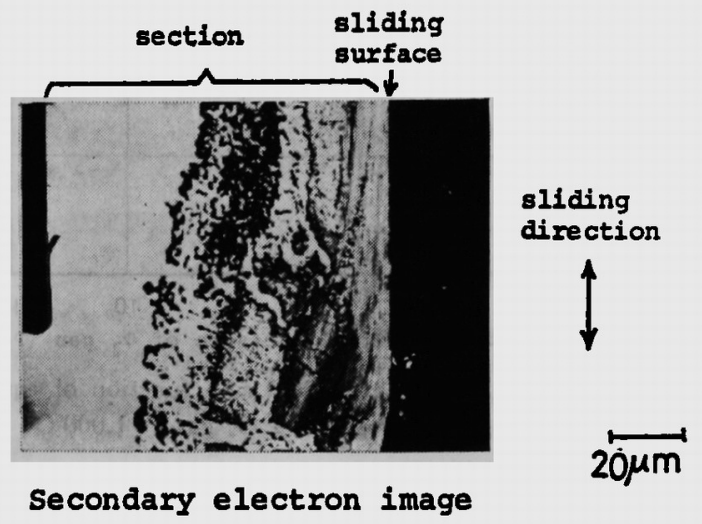

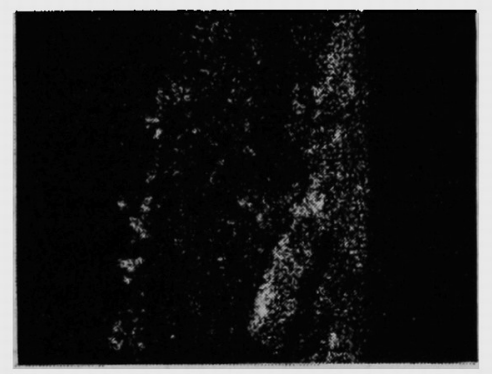

Min

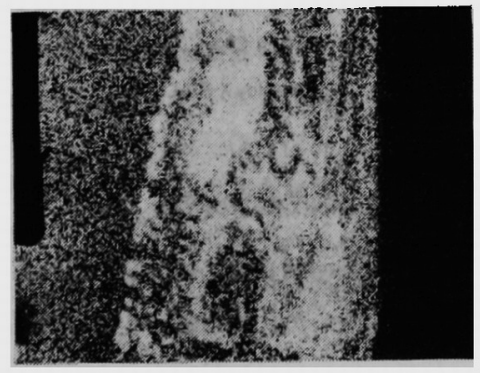

Cr

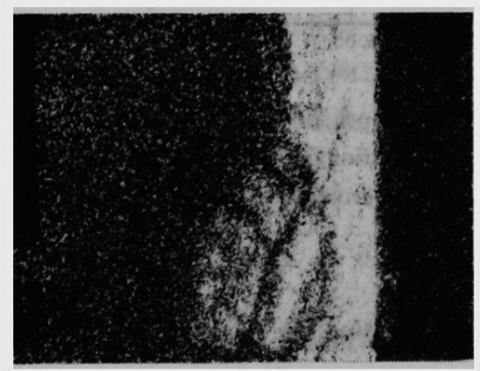

Zr

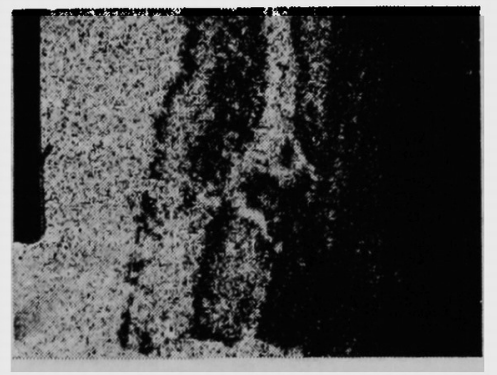

$\mathrm{Fe}$

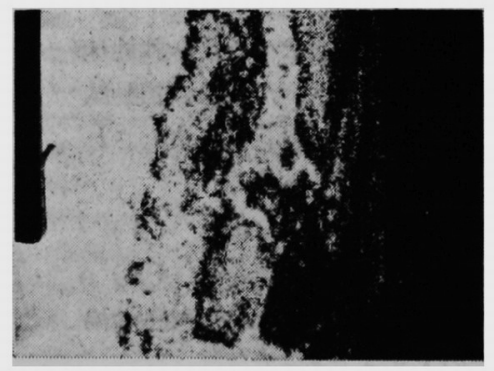

Ni

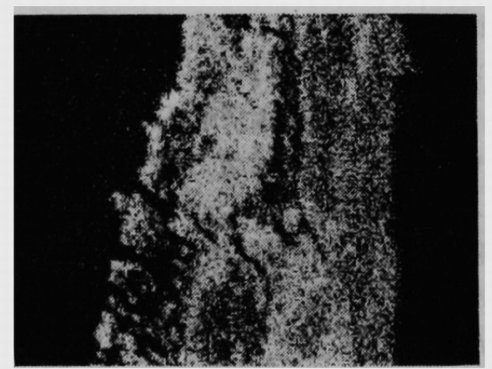

o

Photo. 5 Element analysis for sectional layers of oscillating Hastelloy $\mathrm{X}-\mathrm{R}$ test piece against stationary $\mathrm{ZrO}_{2}-$ $\mathrm{CaC}_{2}$ coating test piece by $\mathrm{X}$-ray microanalyzer 


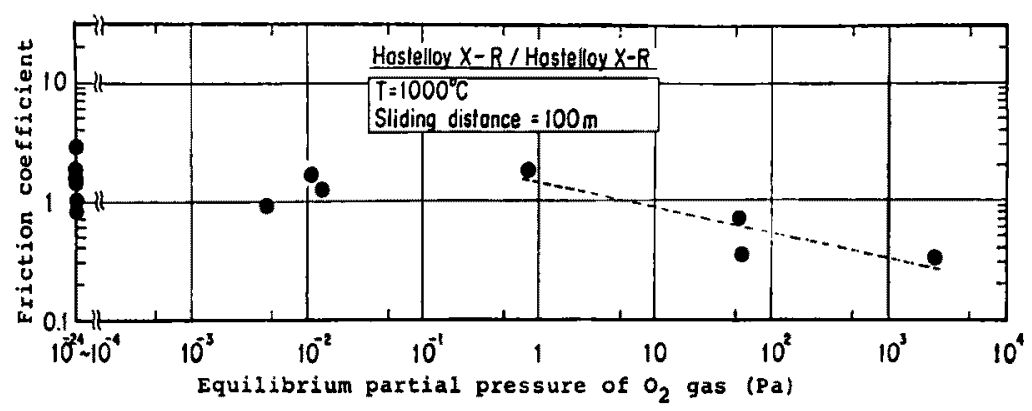

Fig. 7 Friction coefficient as a function of equilibrium partial pressure of $\mathrm{O}_{2}$ gas at $1,000^{\circ} \mathrm{C}$

ら (24)は， $1,000^{\circ} \mathrm{C}$ の純度 $99.999 \%$ He ガスを用いて，

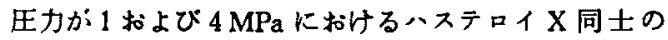
摩察俰数の比較を行なった結果，高い压力下での磨擦 保数が低い压力下での值より大きくなることを報告し

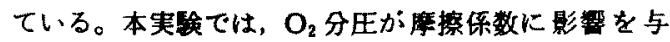

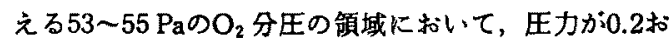
よび4.1 MPa におけりる摩繁係数はそれぞれ0.35拈よび 0.7 であった。すなかち，高い代力はど摩繁係数が大 きくなっており，渡辺らと同じ傾向を示している。

ハステロイ X-R 同士の撌動における摩耗 痕の幅はほぼ2〜4 mmであった。ハステロイ

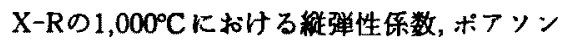
比をそれそれれ $127 \mathrm{GPa} ， 0.3$ をする，弾性球 同士の接触变形 ${ }^{(25)}$ を仮定した場合，摺動試 験片の接触圧力と接螌半径は次式で表わされ る。

$$
\begin{aligned}
& p=160\left\{1-(r / a)^{2}\right\}^{1 / 2} \quad(\mathrm{MPa}) \\
& a=0.17(\mathrm{~mm})
\end{aligned}
$$

すなわち，実際の应耗痕の愊は弾性接触の堎 合の6〜12倍の大きさであった。

ハステロイX-Rとコーティング材およびュ ーティング材同士の捂動では, $\mathrm{Cr}_{23} \mathrm{C}_{8}$ ค $\mathrm{Cr}_{2} \mathrm{O}_{3}$ のコーティング材に制離や龟裂が生じた。 したがって， $1,000^{\circ} \mathrm{C}$ て高温晢動要素への 適用は難しいのではないかと考えられる。 $\mathrm{TiC}$ コーティング材において、コーティング 材同士の摺動では低摩撚俰数・低摩耗量の良好な特性 が得られたが, ハステロイ X-R との揂娌では TiC層が 破られていたので， TiC ューティング材とハステロイ $\mathrm{X}$ - $\mathrm{R}$ の組合せは実機では避けた方が良い。 $\mathrm{ZrO}_{2}$ コーキ ィンク材の摩擦・摩耗特性は，安定化材の種類によら ず安定していた。たたし，コーティング材といステロ イ X-R の材料組合せでは，物貝の相互移着があったの で注意を要する。すなかち、ニーティンダ材の摺動面
には部分的なハステロイ X-R の移着があり，ハステ ロイ X-Rの摺動面にはコーティング材が移着し，酸 化物層との混合層を形成していた。

固定片に用いたコーティング材の表面粗さの変化と コーティング材の硬度との関俰を調べると(Fig.8), 八ステロイ X-R との摺動によって TiC 首が部分的に

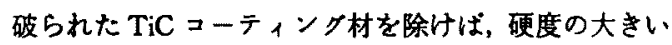
コーティング材はど度耗梁さは小さくなっている。

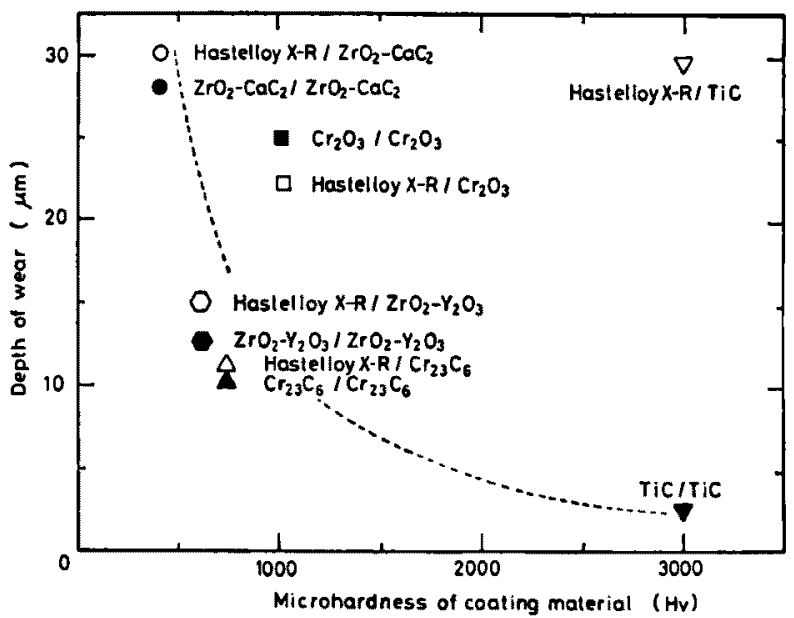

Fig. 8 Depth of wear on sliding surface of stationary test piece as a function of microhardness of coating materials

\section{V. 恄墇}

VHTR 高温粠造部材である $\mathrm{Ni}$ 基耐熱合金鈎(ハス テロイ X-R)の摩擦・摩耗特性に及ぼす等囲気ガスの影 響, およびハステロイX-Rの摺動面にコーティンクし た摺動試片数種類について，原研Bガス中における稀 擦·摩耗特性を調べるため， $1,000^{\circ} \mathrm{C}$ の高温で变位制御 (正弦波)により平面と半球面か接触した面における渭 
勒試験を行なった。得られた結論は以下のとおりであ る。

(1) ハステロイ X-R 同士の摩擦俰数は， $\mathrm{O}_{2}$ 分王か 高いはど低下した。摺動面に形成された $\mathrm{Mn}$ と $\mathrm{Cr}$ の酸化層が潤滑効果をるたらすものと考えられる が，酸化層の下の母材は40〜60 $\mu \mathrm{m}$ の澡さにえぐ り取られていた。

(2) ハステロイ X-R と $\mathrm{ZrO}_{2}-\mathrm{CaC}_{2}, \mathrm{ZnO}_{2}-\mathrm{Y}_{2} \mathrm{O}_{3} \sqsupset-$ ティング材の高温摺動では，物質の相互移籍が認 められた。特に, ハステロイX-Rの摺動面には, 40〜70 $\mu \mathrm{m}$ の厚さの母材の酸化物とコーティンク 材との湿合層が生じていた。

(3) コーティング材同士では, $\mathrm{ZrO}_{2}-\mathrm{CaC}_{2}, \mathrm{ZrO}_{2}-$ $\mathrm{Y}_{9} \mathrm{O}_{3}$, TiC が安定であった。 $\mathrm{ZrO}_{2}$ コーティング村 では，安定化材による摩祭・摩耗特性の差は見ら れなかった。また，TiCは低摩擦俰数・低摩耗量 であった。

\section{[咭号]}

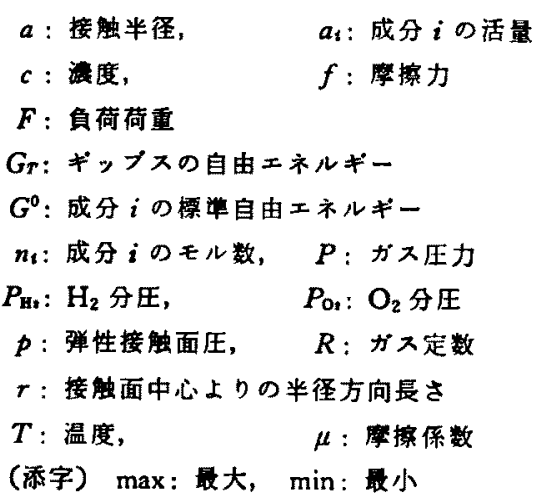

本研究について有益なご討論を頂いた日本原子力研 究所高温工学部高温檴造工学研究室の武藤 康室長, お。 よび混合ガスの高温平衡計算についてご数示頂いた然 料工学部材料工学研究室の合田有司研究員に噰意を表 する。

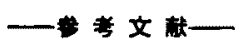

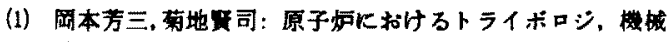
喆, 81(719], 45 52 (1978).

(2) Hedgecock, P.D.: Friction and wear tests on top reflector keyed plenum element materials of the $\mathrm{Ft}$. St. Vrain HTGR, GAMD-9280, (1969).

(3) LAI, G.Y.: Evaluation of sprayed chromium carbide coatings for gas-cooled reactor applications, $G A-A$ 14897, (1978).

(4) LI, C.C., LAI, G.Y.: Sliding wear studies of sprayed chrominum carbide-nichrome coatings for gas-cooled reactor applications, $G A-A 15133$, (1978).

(5) Li,C.C., Sheehan, J.E.: Friction and wear studies of graphite and a carbon-carbon composite in air and in helium, GA-A16054, (1980).

(6) Engel, R., Kleeman, E.: Friction, adhesion and corrosion performance of metallurgical coatings in HTGR-helium, IAEA Specialist's Mtg, on High Temperature Metallic Materials for Application of Gas Cooled Reactors, Vienna, (1981).

(7) 村网 進, 他: 高温ガ ス炣用酎第材料の敢立性, JAERI$M 6088$, (1975).

（8）伊丹宏治, 他: 高温ガス炉用材料の七ラミックコーティン ク, JAERI-M 6127，(1975).

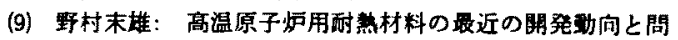
题点，金属会報，16[11]，779 788（1977）.

(10)伊丹宏治，他:原子力学会「昭50年会」要旨菓、E28, (1975).

(11) 伊丹宏治, 他: 同上, E29.

(14) 喜多 清, 他: 同上, E30.

(13) 村瀨宏一，他：川的技報，74，40 45 (1980).

(14)深迫紀夫, 他:原子力学会「昭56年会」要旨集, J 37, (1981).

(15) 深追紀夫, 他: 同上, J 38 .

(16) NeMOTO, M., et al.: Tribological study on machine elements of HTGR components, Mitsubishi Tech. Bull., 146 (1981).

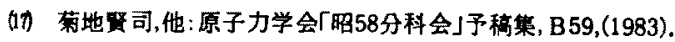

(18) 根本政明, 他: 同上, B60.

(19) Czichos, H.: "Tribology", (1978), Elsevier Sci. Publ,

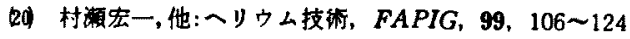
(1981).

(21) SHINDo, M., KONDO, T.: Studies of improving compatibility of nickel-base alloys with high temperature helium-cooled reactor (VHTR) environment, BNES Conf., Gas-coaled Reactor Today, Bristol, (1982).

20 Robert, C.B., Donald, W.W., David, E.B.: Preliminary study of methods for providing thermal shock resistance to plasma-sprayed ceramic gas-path seals, NASA Tech. Paper 1561, (1980).

(23) BESMANN, T.M.: SOLGASMIX-PV, a computer program to calculate equilibrium relationships in complex chemical systems, ORNL/TM-5775, (1977).

(24) WATANABE, S., et al.: Study on tribological characteristics of refractory materials in a high temperature helium atmosphere, ASME Conf. Wear of Materials, Reston, (1983).

(25) TIMOSHENKO,S., GOODIER, J.N.: "Theory of Elasticity", (3rd Ed.), (1970), McGraw-Hill, New York. 